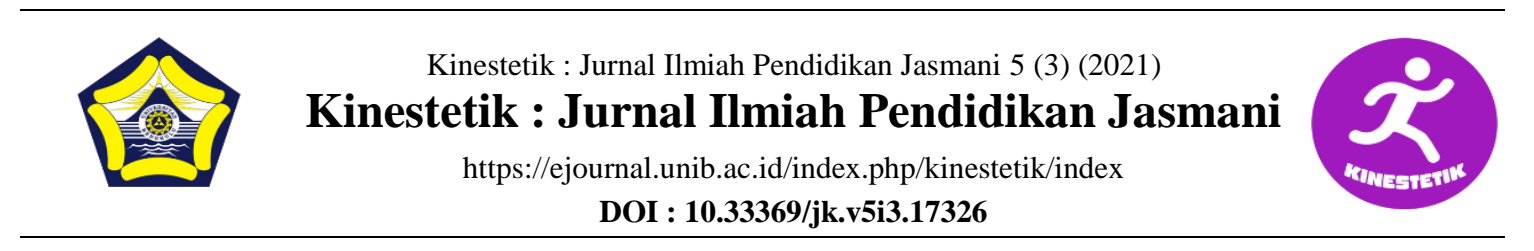

\title{
PHYSICAL FITNESS OF EXTRACURRICULAR STUDENTS PENCAK SILAT TANDING CATEGORY REVIEWED FROM ENDURANCE AND BODY MASS INDEX
}

\author{
Fika Umi Latifah ${ }^{1 *}$, Gatot Jariono ${ }^{2}$ \\ ${ }^{1,2}$ Sports Education, Teacher Training and Education Faculty, Universitas Muhammadiyah \\ Surakarta, Sukoharjo, Indonesia
}

\begin{tabular}{l} 
Article Info \\
\hline Article History : \\
Received :August 2021 \\
Revised :September 2021 \\
Accepted : September 2021 \\
Available online : September \\
2021
\end{tabular}

Keywords:

Endurance, strength, physical fitness, pencak silat

\begin{abstract}
The sample in this study was extracurricular students coaching the achievement of Pencak silat match category in Gemolong District Elementary School Sragen Regency of Central Java Province who participated in training 1 year or more aged 10-12 years as many as 30 students with the provisions of 15 male and 15 female. Quantitative descriptive methods are used in this study while a data analysis technique uses percentage descriptive analysis. The results of this study can be concluded that the physical fitness of extracurricular students Pencak silat match category is reviewed from moderate category endurance for male and less category for female while body mass index characteristics in the category of normal weight. This study only describes physical fitness in terms of endurance and body mass index of elementary school students. For further research will be conducted experimental research with physical fitness training methods by the characteristics of elementary school students who follow extracurricular pencak silat in the counter category as qualified performance support.
\end{abstract}

Corresponding address : Jl. Jayan Rt. 002 Saren Kecamatan

Kalijambe Kabupaten Sragen, Jawa tengah, Indonesia.

*Corresponding email: a810180095@student.ums.ac.id
ISSN 2685-6514 (Online)

ISSN 2477-331X (Print) 


\section{INTRODUCTION}

Pencak silat is a martial art originating from Indonesia that is designated by UNESCO as intangible cultural heritage (Yulio Pratama \& Trilaksana, 2018). The determination was made at the 14th session of the Intergovernmental Committee for the Safeguarding of the Intangible Cultural Heritage, which took place in Bogota, Colombia, December 9-14, 2019 (Agung Nugroho, 2007).

The martial art of pencak silat is also known in other Southeast Asian countries such as Malaysia, Brunei, Singapore, the Philippines, and Thailand. While about movement, in 'Physical Education and Health' by Asep Kurnia Nenggala explained the defenses used in pencak silat are hands, feet, heels, elbows, fingers, and head. Common defense movements are commonly known in pencak silat such as lockdown, loose, elbow, kick to attack using the knee (Ediyono \& Widodo, 2019; Kholis, 2016; Maimun Nusufi, 2015; Prihadianto, 2017; Wilujeng, 2013).

In this study, researchers only chose one of the numbers in pencak silat, namely the matching category. The result is in line with some research results, namely (Amrullah, 2015; Kumaidah, 2012; H. Nugroho et al., 2021; Ulfah \& Walton, 2019) the matching category is pencak silat featuring two fighters from different camps. Pencak silat not only involves physical movements but involves breathing, soul, mental processing and all the spiritual, moral, techniques learned earlier when we begin to learn martial arts.

Pencak silat is a form of active meditation in martial arts because it requires concentration and harmony between the mind, body, and spirit of the practitioner to produce the highest selfawareness to control and combine all the things that have been learned above in a series of movements in synergy.
To learn the pencak silat technique consisting of punches, tanks, kicks, and slams. There is such a thing as cutouts/ movements so that they form legs like scissors to bring down opponents. Pencak silat can be learned by anyone regardless of gender, age, and ability. Pencak silat is a sport of achievement that is growing rapidly in parts of the world.

In sports achievements the need for systematic coaching. This means that a sports coaching system that places the potential coaching and talent of early childhood as the main foundation, furthermore, coaching is carried out through a systematic, tiered, and sustainable training program to achieve high performance (Bompa \& Haff, 2009). To display high performance required systemized exercise to realize complete physical fitness. Thus to improve the physical condition the need for systematic exercise and need to pay attention to aspects of exercise consisting of various disciplines or scientific fields that are incorporated in a training system is inseparable from science (Fachrezzy et al., 2020; Jariono et al., 2020; Jariono \& Subekti, 2020).

Several factors must be considered, including clear coaching goals, systematic training programs, appropriate training materials and methods, and evaluations that can measure the success of the coaching process itself (Arief Parena et al., 2017; Effendi, 2016; Irmansyah, 2017; Parena et al., 2017; Ruslan, 2011b, 2011a; Tangkudung James, 2006).

One indicator of knowing physical fitness is through tests of endurance and body mass index. According to (Indrayana, 2012; Kurnia \& Anggraini, 2020; Nasrulloh, 2015; S. Nugroho, 2007; Rahman, 2018; Sahara et al., 2019; Solissa, 2018) that endurance is the alignment of the body in adjusting the burden of physical activity received to 
perform daily activities without experiencing significant fatigue.

Index body mass is a rate used to find out the nutritional status of a person obtained from the comparison of weight and height. This is in line with the results of research conducted by: (Scientific et al., 2019; Kusumawati et al., 2019; Rahmi Novota Yusuf, 2019; Syauqy, 2019) body mass index is a simple measurement in knowing a person's nutritional status. . One way to assess a person's nutritional status is to measure body mass index (BMI). Measurement and assessment of nutritional status using BMI are done with a mathematical formula of weight (in kilograms) divided by the square of height (in meters).

In identifying more weight and obesity in adults, BMI or body mass index (BMI) is used because measuring body fat directly is very difficult. Some results from BMI measurements can be used to find out if there is a deficiency and excess of a person's nutritional status. (Rahmi Novota Yusuf, 2019) suggests the body mass index shortened to BMI is a simple measurement in knowing a person's nutritional status. A normal BMI is between 20-25. A person is categorized as obese if BMI > 30, overweight when BMI 25-30, and underweight when BMI $<20$.

To approach science and technology to evaluate the ability of physical components of Pencak silat athletes more accurately in the future, research is needed, while in this study is the physical fitness of extracurricular students pencak silat category of the match in terms of endurance and body mass index characteristics.

\section{METHODS}

The descriptive method used in this research is with a quantitative research type approach. The study was conducted from July to August 2021. This study aims to analyze the physical fitness of extracurricular students' pencak silat match category in terms of endurance and body mass index characteristics.

\section{Participants}

This research was conducted in Gemolong District of Sragen Regency of Central Java Province with research samples are all pencak silat athletes numbering 30 people who pencak silat training in the fighting category consisting of 15 male and 15 female.

\section{Sampling Procedures}

This sampling procedure is by purposive sampling. This research requires consideration on the grounds of the characteristics of extracurricular students pencak silat match category who have participated in training 1 year or more age 10-12 years. So in this study, researchers took a sample that had taken a physical fitness test procedure.

\section{Materials and Apparatus}

Data collection techniques using the practice test. Practice tests are used for agility tests using a 600-meter running test to determine the heart endurance of children aged 10-12 years, while body mass index tests based on BMI index scores are obtained from measurements of height and weight and are grouped by WHO standards according to the Asia Pacific group. Provided (i) Under $18.5=$ Less weight; (ii) $18.5-22.9=$ Normal weight; (iii) $23-29.9=$ Excess weight (tendency to obesity); and (iv) 30 and above $=$ obesity . 


\section{Procedures}

The procedures in this study are: (1) the first stage the researcher performs tests and measurements consisting of endurance tests and Body Mass Index; and (2) the researcher categorizes the data that supports and does not support the focus in this research. Then the researcher checks the relationship between the data and field notes so that the data or information that has been obtained in the field can be known

\section{Design or Data Analysis}

The data analysis used in this study is a percentage descriptive analysis. Overall for data analysis using Microsoft Excel 2019 software.

\section{RESULTS}

1. Descriptive analysis of durability percentage

Descriptive analysis of percentages aims to draw in general about the dissemination of the distribution of endurance tests of male and female. A recap of the descriptive analysis of percentage data can be seen in figure 1 .

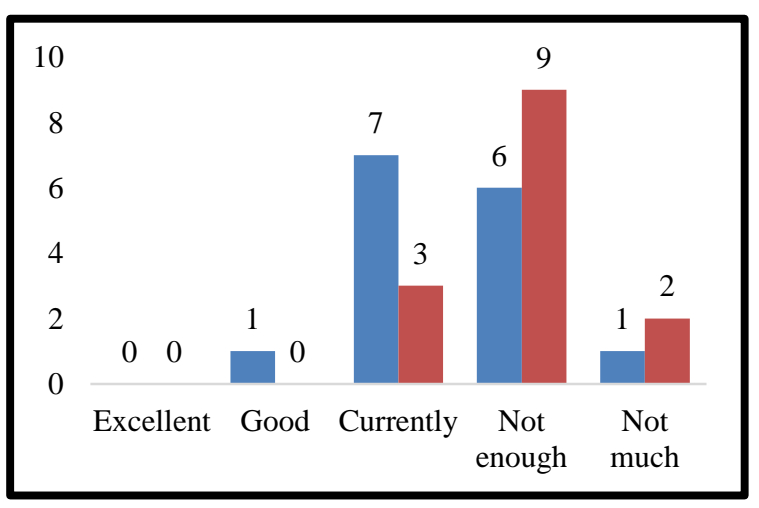

Figure 1. Descriptive histogram percentage of endurance of male and female
Based on the results of the descriptive analysis in figure 1 histogram of physical fitness was reviewed from endurance for men in the medium category while the princess in the category is less. This is evidenced from 30 students who follow the extracurricular pencak silat with the acquisition of each category of physical fitness reviewed from the durability of the category both for sons 1 person and daughter 0 people, medium category for sons 7 people and daughters 3 people, fewer categories for sons 6 people and daughters 9 people, categories are very less for sons 1 person and daughters 2 people, and for good categories there is none. Thus it can be concluded that physical fitness is reviewed from the endurance of the heart for the prince in the medium category while for the princess in the category less. Uniquely from the results of this study in the theory of less than once there is 1 person, for sons and 2 people for female, this there are several factors, one of which is the lack of controlled movement activity caused by social environmental factors and government advice to maintain health protocols with the covid-19 pandemic that hit the world.

2. Descriptive analysis of body mass index (BMI) percentage

Descriptive percentage analysis aims to draw in general regarding the dissemination of the index distribution of body mass. Recap of descriptive analysis of percentage data can be seen in figure 1: 


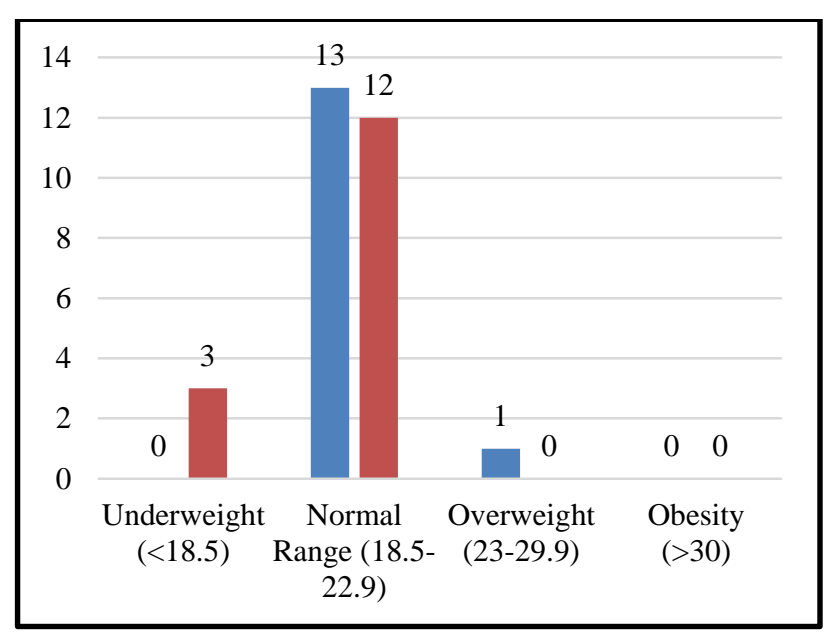

Figure2. Descriptive histogram of BMI percentage

Based on the results of the descriptive analysis in figure 1 histogram of physical fitness was reviewed from body mass index for male and female in the ideal category or have a normal body. This is evidenced from 30 students who participated in extracurricular pencak silat with the acquisition of each category of physical fitness reviewed from BMI category has a normal body for sons 13 people and daughters 12 people, the category of weightless ideal for men 0 people and women 3 people, excess body category for sons 1 person and daughters 0 people, categories are very less for sons 1 person and daughters 2 people, and for obesity does not exist. Thus it can be concluded that physical fitness is reviewed from BMI to be in the theory of normal weight. Uniquely from the results of this study in the theory of obesity, there is 1 person for the prince and 0 people for the princess, this is several factors, one of which is the lack of controlled movement activity caused by social environmental factors and the government's advice to maintain health protocols with the covid19 pandemic that hit the world

\section{DISCUSSION}

The results showed that from the results of descriptive analysis percentage, the physical fitness of students who followed extracurricular pencak silat category match was reviewed from the durability and characteristics of body mass index. Physical fitness is a supporting element of the physical component consisting of strength, speed, agility, coordination, and endurance to carry out daily activities without experiencing significant fatigue and still have physical reserves.

Based on the results of the study, the physical fitness of students who follow the extracurricular pencak silat match category is reviewed from the durability and body mass index characteristics of the Gemolong Subdistrict. These results are supported (Dobbins et al., 2013; Donnelly et al., 2016; Erickson et al., 2014; Rauner et al., 2013) physical fitness is one of the important components to improve the physical component, one of which is to keep the body in shape. (Ozmen \& Aydogmus, 2016; Weiss et al., 2010; Yu et al., 2013) in his research stated that: endurance and characteristics of body mass index as one of the physical components to maintain a person's appearance.

Thus physical fitness training is one of the solutions to be applied in training, especially to increase endurance and body mass index characteristics more effectively and efficiently. This physical fitness exercise is by the characteristics of martial arts pencak silat, especially in the category of match that requires endurance and body mass index characteristics.

The advantage of the physical fitness training method is that the material delivered is in the form of an exercise that is dominantly used in pencak silat in which there are elements of endurance, agility, 
and strength so that athletes do not feel bored in the process of delivering training

\section{CONCLUSION}

The results showed that the physical fitness of extracurricular students of pencak silat match category was reviewed from moderate category endurance for male and less category for female while body mass index characteristics in the normal weight category. Based on the results of this study, researchers concluded that if to improve endurance and body mass index characteristics in athletes pencak silat one of the alternatives through physical fitness exercise and adequate nutritional intake. but the study was limited to describing physical fitness in terms of endurance and body mass index required other variables and conducted experimental research to improve the dominant physical component in students who followed the extracurricular pencak silat category of silat.

\section{ACKNOWLEDGEMENT}

Thanks to the University of Muhammadiyah Surakarta to allow researchers for the Prospective Teacher Driving Program in 2021 and Elementary School Aisyiyah Unggulan Gemolong which has facilitated and provided researchers with the opportunity to conduct research.

\section{REFERENCES}

Amrullah, R. (2015). Pengaruh Latihan Training Resistense Xander Terhadap Kemampuan Tendangan Sabit Pencak Silat. Jurnal Pendidikan Olahraga, 4(1), 88-100.

Arief Parena, A., Rahayu, T., \& Artikel, S.
(2017). Journal of Physical Education and Sports Manajemen Program Pembinaan Olahraga Panahan pada Pusat Pendidikan dan Latihan Pelajar (PPLP) Provinsi Jawa Tengah. Jpes.

Dobbins, M., Husson, H., Decorby, K., \& Larocca, R. L. (2013). School-based physical activity programs for promoting physical activity and fitness in children and adolescents aged 6 to 18. In Cochrane Database of Systematic Reviews. https://doi.org/10.1002/14651858.CD 007651.pub2

Donnelly, J. E., Hillman, C. H., Castelli, D., Etnier, J. L., Lee, S., Tomporowski, P., Lambourne, K., \& Szabo-Reed, A. N. (2016). Physical activity, fitness, cognitive function, and academic achievement in children: A systematic review. In Medicine and Science in Sports and Exercise.

https://doi.org/10.1249/MSS.000000 0000000901

Ediyono, S., \& Widodo, S. T. (2019). Memahami Makna Seni dalam Pencak Silat. Panggung. https://doi.org/10.26742/panggung.v2 9i3.1014

Effendi, H. (2016). Peranan Psikologi Olahraga Dalam Meningkatkan Prestasi Atlet. Nusantara (Jurnal Ilmu Pengetahuan Sosial. https://doi.org/http://jurnal.umtapsel.ac.id/index.php/nusantara/artic le/view/90/90

Erickson, K. I., Leckie, R. L., \& Weinstein, A. M. (2014). Physical activity, fitness, and gray matter volume. In Neurobiology of Aging. https://doi.org/10.1016/j.neurobiolagi ng.2014.03.034

Fachrezzy, F., Jariono, G., Maslikah, U., \& Nugroho, H. (2020). Functional Exercise Model for Weight Loss in Sports Science Faculty Students. 159165. 
Ilmiah, J., Sandi, K., Andini, R., Dokter, P., Kedokteran, F., \& Lampung, U. (2019). LITERATUR REVIEW Indeks Massa Tubuh Sebagai Faktor Risiko Pada Gangguan Muskuloskeletal Metode Hasil Dan Pembahasan. Jurnal Ilmiah Kesehatan Sandi Husada, 10(2), 316-320. https://doi.org/10.35816/jiskh.v10i2. 178

Indrayana, B. (2012). Perbedaan Pengaruh Latihan Interval Training dan Fartlek terhadap Daya Tahan Kardiovaskular pada Atlet Junior Putra Taekwondo Wild Club Medan 2006/2007. Jurnal Cerdas Syifa.

Irmansyah, J. (2017). Evaluasi program pembinaan prestasi cabang olahraga bola voli pantai. Jurnal Keolahragaan. https://doi.org/10.21831/jk.v5i1.1275 9

Jariono, G., Nursubekti, N., Indarto, P., Hendarto, S., Nugroho, H., \& Fachrezy, F. (2020). Analisis kondisi fisik menggunakan software Kinovea pada atlet taekwondo Dojang Mahameru Surakarta. Transformasi: Jurnal Pengabdian Masyarakat. https://doi.org/10.20414/transformasi .v16i2.2635

Jariono, G., \& Subekti, N. (2020). Sports Motivation Survey And Physical Activity Students Of Sport Education Teacher Training And Education Faculty FKIP Muhammadiyah University Surakarta. Kinestetik: Jurnal Ilmiah Pendidikan Jasmani. https://doi.org/10.33369/jk.v4i2.1244 9

Kholis, N. (2016). Aplikasi Nilai-Nilai Luhur Pencak Silat Sarana Membentuk Moralitas Bangsa. Jurnal SPORTIF : Jurnal Penelitian Pembelajaran.

https://doi.org/10.29407/js_unpgri.v2 i2. 508

Kumaidah, E. (2012). Penguatan Eksistensi Bangsa Melalui Seni Bela
Diri Tradisional Pencak Silat. Jurnal Humanika.

Kurnia, M., \& Anggraini, H. (2020). Pengaruh Latihan Jogging Terhadap Daya Tahan Kardiorespirasi Pada Atlet Taekwondo Survivar 5 Club Palembang. Halaman Olahraga Nusantara (Jurnal Ilmu Keolahragaan). https://doi.org/10.31851/hon.v3i1.35 58

Kusumawati, E., Lusiana, N., Mustika, I., Negeri, I., \& Ampel, S. (2019). Anemia defisiensi besi dan indeks massa tubuh terhadap siklus menstruasi remaja. JURNAL KESEHATAN, 12(1), 30-40. https://doi.org/https://doi.org/10.2425 2/kesehatan.v12i1.7157

Maimun Nusufi. (2015). Hubungan Kelentukan Dengan Kemampuan Kecepatan Tendangan Sabit Pada Atlet Pencak Silat Binaan Dispora Aceh (Pplp Dan Diklat) Tahun 2015. Ilmu Keolahragaan.

Nasrulloh, A. (2015). Pengaruh Latihan Circuit Weight Training Terhadap Kekuatan Dan Daya Tahan Otot. Medikora, $\operatorname{VIII}(2)$. https://doi.org/10.21831/medikora.v0 i2. 4652

Nugroho, H., Gontara, S. Y., Angga, P. D., Jariono, G., \& Maghribi, I. L. (2021). Quality Of Physical Condition Of Youth Pencak Silat Athletes Reviewed From Speed, Power. Kinestetik : Jurnal Ilmiah Pendidikan Jasmani, 5(1), 154-162. https://ejournal.unib.ac.id/index.php/ kinestetik/article/view/14376

Ozmen, T., \& Aydogmus, M. (2016). Effect of core strength training on dynamic balance and agility in adolescent badminton players. Journal of Bodywork and Movement Therapies. https://doi.org/10.1016/j.jbmt.2015.1 2.006 
Parena, A. A., Rahayu, T., \& Sugiharto. (2017). Manajemen Program Pembinaan Olahraga Panahan pada Pusat Pendidikan dan Latihan Pelajar (PPLP) Provinsi Jawa Tengah. Journal of Physical Education and Sports.

Prihadianto, R. (2017). Hubungan Antara Power Otot Tungkai Dan Kelincahan Terhadap Kecepatan Tendangan Depan Dan T Pada Cabang Olahraga Pencak Silat. Jurnal Universitas Nusantara PGRI KEDIRI.

Rahman, F. J. (2018). Peningkatan Daya Tahan, Kelincahan, dan Kecepatan pada Pemain Futsal: Studi Eksperimen Metode Circuit Training. Jurnal SPORTIF: Jurnal Penelitian Pembelajaran.

https://doi.org/10.29407/js_unpgri.v4 i2. 12466

Rahmi Novota Yusuf, I. (2019). Jurnal Kesehatan Saintika Meditory Correlation Of Body Mass Index ( BMI ) With Cholesterol Jurnal Kesehatan Saintika Meditory. Jurnal Kesehatan Saintika Meditory, 1(2), 50-56.

https://jurnal.syedzasaintika.ac.id

Rauner, A., Mess, F., \& Woll, A. (2013).

The relationship between physical activity, physical fitness and overweight in adolescents: A systematic review of studies published in or after 2000. BMC Pediatrics.

https://doi.org/10.1186/1471-243113-19

Ruslan. (2011a). Meningkatkan Kondisi Fisik Atlet Pusat Pendidikan. Ilara.

Ruslan. (2011b). Meningkatkan Kondisi Fisik Atlet Pusat Pendidikan dan Latihan Olahraga Pelajar (PPLP) di Provinsi Kalimantan Timur. Ilara.

Sahara, M. P., Widyastuti, N., \& Candra, A. (2019). Kualitas Diet Dan Daya Tahan (Endurance) Atlet Bulutangkis Remaja Di Kota Semarang. Journal of
Nutrition College. https://doi.org/10.14710/jnc.v8i1.238 10

Solissa, J. (2018). Pengaruh Metode Latihan Dan Kekuatan Terhadap Daya Tahan Tendangan Taekwondo. Gelanggang Pendidikan Jasmani Indonesia. https://doi.org/10.17977/um040v2i1p $18-24$

Syauqy, A. (2019). Gambaran Indeks Massa Tubuh dan Densitas Massa Tulang sebagai Faktor Risiko Osteoporosis pada Wanita The Profile of Body Mass Index and Bone Mass Density Scan as Osteoporosis Risk Factor among Female. Jurnal Kedokteran Brawijaya, 30(3), 218222. https://doi.org/DOI: http://dx.doi.org/10.21776/ub.jkb.201 9.030.03.10

Ulfah, W. A., \& Walton, E. P. (2019). Pengaruh Latihan Sirkuit Training Terhadap Kecepatan Tendangan Sabit Pada Siswa Ekstrakulikuler Pencak Silat. SPORTIVE: Journal Of Physical Education, Sport and Recreation. https://doi.org/10.26858/sportive.v2i 2.8492

Weiss, T., Kreitinger, J., Wilde, H., Wiora, C., Steege, M., Dalleck, L., \& Janot, J. (2010). Effect of Functional Resistance Training on Muscular Fitness Outcomes in Young Adults. Journal of Exercise Science and Fitness. https://doi.org/10.1016/S1728$869 X(10) 60017-2$

Wilujeng, W. A. (2013). Hubungan Kecepatan Terhadap Kecepatan Tendangan Sabit di SMP Muhammadiyah 2 Surabaya (studi pada siswa ekstrakurikuler pencak silat tapak suci). Jurnal Pendidikan Olahraga Dan Kesehatan.

Yu, J. H., Park, D. S., \& Lee, G. C. (2013). Effect of eccentric strengthening on 
Fika Umi Latifah et al/ Kinestetik : Jurnal Ilmiah Pendidikan Jasmani 5 (3) (2021)

pain, muscle strength, endurance, and functional fitness factors in male patients with achilles tendinopathy. American Journal of Physical Medicine and Rehabilitation. https://doi.org/10.1097/PHM.0b013e 31826eda63

Yulio Pratama, R., \& Trilaksana, A. (2018). Perkembangan Ikatan Pencak Silat Indonesia (Ipsi) Tahun 19481973. Avatara. 